\title{
The utility of CAD in recovering Gondwanan vicariance events and the evolutionary history of Aciliini (Coleoptera: Dytiscidae)
}

\author{
Rasa Bukontaite ${ }^{1,2^{*}}$, Kelly B Miller ${ }^{3}$ and Johannes Bergsten ${ }^{1}$
}

\begin{abstract}
Background: Aciliini presently includes 69 species of medium-sized water beetles distributed on all continents except Antarctica. The pattern of distribution with several genera confined to different continents of the Southern Hemisphere raises the yet untested hypothesis of a Gondwana vicariance origin. The monophyly of Aciliini has been questioned with regard to Eretini, and there are competing hypotheses about the intergeneric relationship in the tribe. This study is the first comprehensive phylogenetic analysis focused on the tribe Aciliini and it is based on eight gene fragments. The aims of the present study are: 1) to test the monophyly of Aciliini and clarify the position of the tribe Eretini and to resolve the relationship among genera within Aciliini, 2) to calibrate the divergence times within Aciliini and test different biogeographical scenarios, and 3) to evaluate the utility of the gene CAD for phylogenetic analysis in Dytiscidae.

Results: Our analyses confirm monophyly of Aciliini with Eretini as its sister group. Each of six genera which have multiple species are also supported as monophyletic. The origin of the tribe is firmly based in the Southern Hemisphere with the arrangement of Neotropical and Afrotropical taxa as the most basal clades suggesting a Gondwana vicariance origin. However, the uncertainty as to whether a fossil can be used as a stem-or crowngroup calibration point for Acilius influenced the result: as crowngroup calibration, the 95\% HPD interval for the basal nodes included the geological age estimate for the Gondwana break-up, but as a stem group calibration the basal nodes were too young. Our study suggests CAD to be the most informative marker between 15 and $50 \mathrm{Ma}$.

Notably, the 2000 bp CAD fragment analyzed alone fully resolved the tree with high support.

Conclusions: 1) Molecular data confirmed Aciliini as a monophyletic group. 2) Bayesian optimizations of the biogeographical history are consistent with an influence of Gondwana break-up history, but were dependent on the calibration method. 3) The evaluation using a method of phylogenetic signal per base pair indicated Wnt and CAD as the most informative of our sampled genes.
\end{abstract}

Keywords: CAD, Phylogenetic informativeness, Adephaga, Biogeography, Phylogeny, Aciliini

\section{Background}

The tribe Aciliini Thomson, 1867 belongs to the subfamily Dytiscinae, comprising most of the larger diving beetles within Dytiscidae. Aciliini presently include 69 described species in seven genera [1]. Adults have generally good flight capability and can be found in both

\footnotetext{
* Correspondence: rasa.bukontaite@nrm.se

'Department of Entomology, Swedish Museum of Natural History, Box 50007, SE-104 05 Stockholm, Sweden

2Department of Zoology, Stockholm University, SE-106 91 Stockholm, Sweden

Full list of author information is available at the end of the article
}

temporary and permanent water bodies [2-4]. They are distributed worldwide and mostly inhabit standing waters like pools, ponds, lakes, swamps and bogs $[1,3,4]$. Both larvae and adults are predatory on smaller aquatic invertebrates and the larvae have a characteristic arched body shape with a small narrow head.

The distribution of the tribe covers all main zoogeographical regions except Antarctica, but distribution of the genera suggests an ancient origin (Figure 1). Thermonectus Dejean, 1833 is the most speciose genus of the tribe (with eighteen species) and occurs in the Neotropics and the Nearctic north to the Canadian border [2]. The 




Figure 1 Approximate geographical distribution of Aciliini genera.

genera Acilius Leach, 1817 and Graphoderus Dejean, 1833, which each include more than ten species, are restricted to the Holarctic. Aethionectes Sharp, 1882 is a small Afrotropical genus with eight species, one of which is restricted to Madagascar. Sandracottus Sharp, 1882 occurs in the Australasian region. Rhantaticus Sharp, 1882 is a widespread genus with currently a single recognized species $R$. congestus (Klug, 1833) occurring throughout the Afrotropical, south Palearctic, Oriental and Australian regions. However, preliminary studies suggest that it is a species complex in need of revision. Finally, the most recently added genus Tikoloshanes Omer-Cooper, 1956 includes the single species T. eretiformis Omer-Cooper, 1956. It is rarely collected, never in great numbers, and only known from southeastern Africa. Tikoloshanes share similarities with the tribe Eretini Crotch, 1873 as the color and shape are very similar to those of Eretes Laporte, 1833, but the genus was proposed as a new genus within Aciliini, close to Aethionectes [5]. Tikoloshanes has never been included in a phylogenetic analysis using molecular data. The tribe Aciliini has not previously undergone any major revision or phylogenetic analysis, but the genus Acilius was recently revised [3] and its evolutionary history inferred with molecular and morphological data [6].
Erichson [7] referred species today in Graphoderus, Sandracottus and Thermonectus to Hydaticus until 1833 when Dejean [8] recognized Thermonectus and Graphoderus as separate genera. Aubé [9] transferred Thermonectus to a subgroup of Acilius and Graphoderus to a subgroup of Hydaticus. Régimbart [10] was the first author who suggested a delimitation of Acilius, Graphoderus and Hydaticus similar to the one used today based on characters of the metasternal wing and metatibial spurs, but Thermonectus and Sandracottus were included in Graphoderus. A few years later, Sharp [11] formalized this view, erected the tribes Thermonectini (=Aciliini) and Hydaticini, and recognized the six genera of Aciliini which are generally accepted today (except the more recently described Tikoloshanes). Hence, since the early classification there has been two alternative hypotheses. First, the genus Acilius has been regarded as the most divergent of the genera based on morphology, especially that of the females and the wide body shape. This is reflected in, for example, Erichson's [7] classification, with Graphoderus, Sandracottus and Thermonectus grouped with each other near Hydaticus. An alternative hypothesis is the view of Aubé [9] that there are 
similarities between Acilius and Thermonectus to the exclusion of the other genera. These hypotheses are mutually exclusive if similarity is to be interpreted as evidence of sister group relationships, although they were erected prior to the development of a cladistic theory and could reflect similarity based on shared plesiomorphic character states.

The evolutionary relationships of Aciliini genera have never been analyzed in detail with modern phylogenetic methods. Only a handful of studies with different foci have included a few representatives in phylogenetic analyses. Miller's [12] study on Dytiscinae was based on adult morphology and recovered Graphoderus as a group sister to the rest of Aciliini, and Acilius and Thermonectus as sister clades in agreement with Aubé [9]. In a later morphological study, with a larger taxon sampling for all of Dytiscidae and with a focus on the female reproductive tract, Miller [13] included all known genera of Aciliini. However the genera Aethionectes, Rhantaticus, Sandracottus and Tikoloshanes were merged into a single terminal as they scored identically for all morphological characters used. Again, Acilius and Thermonectus came out as sister taxa [13].

In a molecular study Ribera et al. [14] included single representatives of five of the seven Aciliini genera and arrived at a somewhat different intergeneric topology. In their analysis Acilius instead came out as sister to Graphoderus, and Thermonectus was placed as sister to this clade. Also Rhantaticus and Sandracottus were identified as sister groups and, together, sister to the rest of Aciliini. Moreover they recovered Eretini nested inside Aciliini suggesting the tribe may be paraphyletic. Only the first conclusion was strongly supported with posterior probability of $>0.95$. However their main focus was on the phylogeny of supra-generic groups of Dytiscidae based on two mitochondrial and two nuclear genes, including five species of Aciliini and two species of Eretini. Eretini, which includes only the genus Eretes, has been proposed to be the sister tribe to Aciliini, since it shares similar setae on the metafemur which are apically bifid and arranged in a strongly oblique row [12,15]. The larvae also share a unique shape, an erratic shrimp-like swimming-escape behavior and two pairs of large camera-like stemmata which may be an additional apomorphy for Aciliini and Eretini [16]. The prospect of a paraphyletic Aciliini with Eretini nested inside was quite surprising, but tantalizingly suggests the possibility that the enigmatic Tikoloshanes eretiformis is, indeed, closely related to Eretini.

A dated phylogenetic hypothesis with robust support is needed in order to test whether the intergeneric relationships in the group, and the age of the group, supports a Gondwana break-up origin. Both the hypotheses outlined above contradict such an origin. Acilius basal would infer a Holarctic origin of the group and an Acilius + Thermonectus sister group relationship would imply a much more recent Holarctic-Neotropical connection and diversification. Neither is consistent with a Gondwana break-up origin, which would require basal positions of southern hemisphere clades. Fossils in the tribe are very sparse and of no direct help to place the origin of the group in the Cretaceous as all are of younger Neogene or late Paleogene ages. However, the use of relaxed clock models and Bayesian frameworks to include the calibration uncertainty as prior distributions can make use of such fossil to derive age span estimates for the basal nodes in a well-supported tree.

The search for new nuclear coding genes for phylogeny reconstruction in different target groups is ongoing [17]. Coleoptera does not contain any high priority model organisms except perhaps the flour beetle, Tribolium castaneum, but its complete genome was not entirely sequenced until 2008 [18], which is one reason the selection of easily amplifiable single-copy nuclear genes in beetles has lagged behind many other groups of organisms. The nuclear protein-coding gene CAD, also known as rudimentary, was for the first time introduced to the insect systematics community by Moulton and Wiegmann [17]. Since then it was successfully used in e.g. Diptera [17], Hymenoptera [19-21], Neuropterida [22], Trichoptera [23] and Lepidoptera studies [24]. CAD performed well both separately and in combination with other genes as evaluated by Johanson and Malm [23]. Some studies to date have used CAD in Coleoptera [25-34], mainly in Carabidae, Scolytinae and Silphidae but none have yet used CAD in Adephagan water beetle (Hydradephaga) phylogenetics.

The CAD gene encodes three enzymes that catalyze pyrimidine biosynthesis: carbamoyl phospate synthetase (CPS), aspartate transcarbamylase (ATC) and dihydroorotase (DHO) and with a combined total length of about $6.6 \mathrm{~kb}$. Recent studies on Braconidae by Sharanowski et al. [35] demonstrated that the CPS region contains a high number of parsimony informative sites. Wild and Maddison [27] suggested CAD to be the highest performing gene fragment for both shallow and deep phylogenetics among eight evaluated nuclear genes in beetles and designed several primer pairs for a $2020 \mathrm{bp}$ CPS region, free of introns in most taxa of beetles.

This study is the first comprehensive phylogenetic analysis focused on the tribe Aciliini and it is based on eight gene fragments. The aims of the present study are: 1) to test the monophyly of Aciliini, clarify the position of the tribe Eretini and to resolve the relationship among genera within Aciliini 2) to calibrate the divergence times within Aciliini, reconstruct ancestral distributions and thereby test the hypothesis of a Gondwana vicariance 
influence, and 3) to evaluate the utility of CAD for phylogenetic analysis in Dytiscidae.

\section{Methods}

\section{Taxon sampling}

Taxon sampling was focused on assembling the highest species representation as possible for the tribes Aciliini and Eretini. Our ingroup comprised species from all seven genera of Aciliini (61\% of the known Aciliini species): Acilius (12 species, 92\%), Aethionectes (2 species, 25\%), Graphoderus (10 species, 91\%), Rhantaticus (1 species, 100\%), Sandracottus (5 species, 31\%), Thermonectus (11 species, 58\%), Tikoloshanes (1 species, 100\%), and all four species of Eretini represented by the single genus Eretes. Our taxa cover all six zoogeographic regions: Nearctic (Acilius, Graphoderus, Thermonectus), Neotropical (Thermonectus), Palearctic (Acilius, Graphoderus, Sandracottus, Rhantaticus), Afrotropical (Aethionectes, Rhantaticus, Tikoloshanes), Oriental (Rhantaticus, Sandracottus) and Australian (Sandracottus, Rhantaticus) (see Additional file 1: Table S1).

Since Rhantaticus congestus is suspected to actually represent a species complex we included several specimens of Rhantaticus from different regions. As outgroups to root the tree we used representatives from Hydaticini, which are thought to be the closest relatives [12], and Dytiscini.

\section{DNA extraction, amplification and sequencing methods}

For most specimens whole genomic DNA was extracted using Qiagen DNEasy kit (Valencia, California, USA) and the animal tissue protocol. Thoracic muscle tissue was removed from large specimens for extraction. A few small specimens were extracted by removing the abdomen and placing the remaining portion of the specimen in extraction buffer for incubation. Dissected specimens and whole extracted specimens were retained for vouchering in the Museum of Southwestern Biology Division of Arthropods (MSBA, K.B. Miller, curator). Some DNA was extracted from legs of ethanol-preserved or dry-mounted material using the DNEasy DNA extraction kit (Qiagen, Valencia, CA) following the manufacturer's recommendation, except for that $20 \mu \mathrm{l}$ of 1 molar DTT (dithiothreitol) was added during the lysis stage. The GeneMole robot and MoleStrips ${ }^{\mathrm{mi}}$ DNA Tissue (Mole Genetics) was used for isolation of DNA from some of the samples with an elution volume of $100 \mu \mathrm{l}$. After extraction, legs were returned to the vouchers for archiving.

Eight gene fragments were selected to infer the phylogeny and divergence times. These included three nuclear protein-coding genes, histone $3(\mathrm{H} 3)$, wingless (Wnt) and rudimentary (CAD, a part of CPS), two ribosomal genes, mitochondrial $16 \mathrm{~S}$ and nuclear $28 \mathrm{~S}$, and the mitochondrial protein-coding genes cytochrome c oxidase subunit
I (COI) and II (COII). COI was sequenced in two nonoverlapping fragments. Primers used for amplification and sequencing were derived from several sources, but also new primers were designed for some taxa (see Additional file 2: Table S2).

Most of the DNA fragments were amplified using "Ready-to-go" ${ }^{\text {nu" }}$ PCR Beads from Pharmacia Biotech following the manufacture's standard protocols. Each $25 \mu \mathrm{l}$ reaction contained $1 \mu \mathrm{l}$ of $10 \mu \mathrm{M}$ primer pair mix $(\times 2)$, $2 \mu \mathrm{l}$ of DNA template and $21 \mu \mathrm{l}$ of water. The thermal cycling profile for "Ready-to-go" PCR was $94^{\circ} \mathrm{C}$ for $5 \mathrm{~min}$, followed by 40 cycles of $94^{\circ} \mathrm{C} 30 \mathrm{~s}, 56-50^{\circ} \mathrm{C}$ for $30 \mathrm{sec}, 72^{\circ} \mathrm{C}$ for $1 \mathrm{~min}$ and finally $72^{\circ} \mathrm{C}$ for $8 \mathrm{~min}$. Product yield, specificity of amplification and contamination were investigated using agarose gel electrophoresis. PCR products were purified using ExoFast Cleanup mix (Fermentas) and cycle sequenced using the same primers as in the PCR. For sequencing reactions the ABI BigDye Terminator kit ver. 3.1 kit (Applied Biosystems) was used. Each sequencing reaction mixture included $1 \mu \mathrm{l}$ of BigDye $^{\text {tm }}$ (Applied Biosystems), $1 \mu \mathrm{l}$ of 1,6 $\mu \mathrm{M}$ primer and $2-4 \mu \mathrm{l}$ of PCR product. The sequence cycling profile was $95^{\circ} \mathrm{C}$ for $1 \mathrm{~min}$ and then 25 cycles of $95^{\circ} \mathrm{C} 30 \mathrm{sec}, 50^{\circ} \mathrm{C}$ $15 \mathrm{sec}$ and $60^{\circ} \mathrm{C} 4 \mathrm{~min}$. Sequencing products were purified using the DyeEx 96 kit and fragments were analyzed on an ABI377xl analyzer from Applied Biosystems at the Molecular Systematics Laboratory, Swedish Museum of Natural History.

Some fragments were amplified using PCR with TaKaRa Amplitaq (Applied Biosystems, Foster City, CA, USA) on an Eppendorf Mastercycler ep gradient $\mathrm{S}$ thermal cycler (Eppendorf, Hamburg, Germany). Amplification conditions were similar to those used by Miller et al. $[6,36,37]$. Products were purified using ExoSAP-IT (USB-Affymetrix, Cleveland, $\mathrm{OH}, \mathrm{USA}$ ) and cycle sequenced using $\mathrm{ABI}$ Prism Big Dye (v3.1; Invitrogen, Fairfax, VA, USA) using the same primers as for amplification. Sequencing reaction products were purified using Sephadex G-50 Medium (GE Healthcare, Uppsala, Sweden) and sequenced using an ABI3130xl Genetic Analyzer (Applied Biosystems, Foster City, CA, USA) in the Molecular Biology Facility at the University of New Mexico.

Gene regions were sequenced in both directions. Resulting sequence data were examined and edited using the program Sequencher 4.10 (Gene Codes Corporation). The forward and reverse primers were trimmed from the beginning and end of each sequence. Sequences are submitted to NCBI GenBank under accession numbers KF978819KF979120.

For some taxa we did not retrieve full length fragments, probably due to DNA degradation especially for the dry-pinned specimens. Sequences from all eight gene fragments were obtained from specimens when possible and missing data represented $11 \%$ at the gene fragment 
level. DNA sequences were aligned with MUSCLE [38] in MEGA 5 [39] using the default settings. The proteincoding genes contained no gaps except for CAD which had a 3, 6 or $9 \mathrm{bp}$ long indel at one position. The final alignment of the eight gene segments included $6095 \mathrm{bp}$ and all gaps were treated as missing data in the analyses. Data tables and matrices were created with Voseq 1.4.4 [40].

\section{Partition finder}

To determine the best-fit partitioning scheme of molecular evolution for our dataset we used PartitionFinder V1-1.0.1 [41]. During analyses branch lengths were unlinked to allow the program to estimate them independently for each subset. The best model, among the ones available in MrBayes 3.2 [42], was searched for under the greedy search algorithm based on the Bayesian Information Criterion (BIC) model metric. Based on BIC scores for each partition, GTR + I + G or HKY + G model were the best-scoring models, followed closely by the SYM + I + $\mathrm{G}$ and $\mathrm{HKY}+\mathrm{I}+\mathrm{G}$ models. We used the partitioning scheme and among-site rate variation suggested by PartitionFinder but instead of selecting one substitution model a priori, we used reversible-jump MCMC to allow sampling across the entire substitution rate model space [43] (see Additional file 3: Table S3). Apart from using the partitioning scheme suggested by Partition Finder, we also tested partitioning our data following a commonly suggest scheme with six partitions [37]: 1) $1^{\text {st }}$ and $2^{\text {nd }}$ codon position of mitochondrial protein-coding genes, 2) $3^{\text {rd }}$ codon position of mitochondrial protein-coding genes, 3) $1^{\text {st }}$ and $2^{\text {nd }}$ codon position of nuclear proteincoding genes, 4) $3^{\text {rd }}$ codon position of nuclear proteincoding genes, 5) mitochondrial ribosomal genes (16S), 6) nuclear ribosomal genes $(28 \mathrm{~S})$.

\section{Phylogenetic analyses}

We used Bayesian inference to estimate the phylogenetic relationship among taxa. Four taxa were used as outgroups: Hydaticus aruspex Clark, 1864, Hydaticus transversalis Pontoppidan, 1763, Hydaticus leander Rossi, 1790 and Dytiscus verticalis Say, 1823. Hydaticini is considered to be the closest relative to Aciliini + Eretini among the outgroups included in this study [12,14]. Data were first examined by analyzing the different gene regions separately. The final phylogenetic analysis was conducted on the combined data matrix of all eight gene fragments.

The partitioned data set was analyzed by Bayesian methods using Metropolis-coupled Markov Chain Monte Carlo (MCMC) in MrBayes 3.2 [42]. All partitions were unlinked allowing each partition to have its own set of parameters. The analysis was run with four chains for 10000000 generations with a sample frequency of 1000 and a burn-in value of $25 \%$. The parameter estimations were checked in Tracer v 1.5. [44].

All analyses were repeated twice to ensure that the final trees converged to the same topology and convergence of runs was monitored with the statistics provided by MrBayes 3.2. The final tree was visualized in FigTree 1.3 and annotated with Adobe Illustrator CS5.

To ensure that the MCMC analyses had run long enough such that tree topologies were sampled in proportion to their true posterior probability distribution, we used AWTY $[45,46]$ for graphical visualization of $\mathrm{MCMC}$ convergence.

\section{Dating analysis}

A calibrated tree was obtained using the topology retrieved from MrBayes in a Bayesian MCMC analysis with BEAST 1.7.5 [44]. We used the same partitions as in the MrBayes analyses. Since Beast does not allow the reversible jump MCMC the General Time Reversible substitution model with gamma and invariant sites $(\mathrm{GTR}+\Gamma+\mathrm{I})$ was selected. The uncorrelated lognormal clock was used to relax the equal rates constraint across the tree that a strict clock enforces [47].

Our primary calibration point was based on the fossil of Acilius florissantensis Wickham, 1909. The fossil is from the Florissant formation in Colorado, USA, which occurs on the boundary between Oligocene and Eocene, and has been dated to $34.07+/-0.10 \mathrm{Ma}$ [48]. Based on the description of the fossil it is possible to either associate the fossil with the monophyletic Nearctic clade of Acilius [6] or to the whole genus. The narrower bodyshape is in agreement with the Nearctic clade (as is the location of the formation), and Wickham [49] mainly compared the fossil with Nearctic A. semisulcatus Aubé, 1838. But that body-shape is also found in one of the Palearctic species (A. duvergeri Gobert, 1874) and it is ambiguous if this is the apomorphic or plesiomorphic state in the genus. The fossil is a ventral impression of a male, whereas a dorsal female impression could have been more informative. Because of this uncertainty in placement we tested the effect of using it both as a stem-node constraint of Acilius and as a crown-node constraint of Acilius, the latter appropriate if the fossil can be assigned to the Nearctic clade. The prior on the age of the node was set to a lognormal distribution with an offset at $34,0 \mathrm{Ma}$ (mean $=7$, Std $=5,0$ ), which gave a distribution with median at $40 \mathrm{Ma}$ and $95 \%$ of the prior distribution between 36 and $50 \mathrm{Ma}$. As a fossil only represents a minimum age of a node and the real age is likely to be some amount older followed by a declining tail of probability further back, this lognormal prior captures more or less our prior beliefs $[50,51]$.

We also performed the same analyses using an exponential prior (offset $=34 \mathrm{Ma}$, mean $=5,95 \%$ of the distribution 
between 34 and $52 \mathrm{Ma}$ ) instead of a lognormal prior (see [50] for a discussion of the use of exponential versus lognormal distribution to model fossil calibration uncertainty). The results were very similar compared to the difference of using the fossil on either the stem or crown node, why only the lognormal and the node of calibration will be discussed further.

Proposals for updating the topology in the MCMC chain were inactivated so that only branch lengths were estimated in this analysis. The analysis was run for 30000000 generations sampled every 3000 generations with a burn-in value of $10 \%$. We used TreeAnnotator to calculate the maximum clade credibility tree and visualized it in FigTree.

\section{Biogeographic analyses}

We used Bayesian Binary Method (BBM) implemented in RASP (Reconstruct Ancestral State in Phylogenies) [52] to reconstruct the ancestral areas of Aciliini. The current distribution areas of species (Figure 1) were obtained from Nilsson [1] and coded as follows: A (Nearctic), B (Neotropical), C (Afrotropical), D (Oriental), E (Australian), F (Palearctic). The analysis was conducted on the dated tree based on the primary calibration point as a crown group constraint of Acilius with the lognormal prior distribution. The outgroup taxa were removed from the analyses, since the model assigns virtual outgroups to the phylogenetic tree prior to the start of the analyses.

The four MCMC chains were run simultaneously for 10000000 generations. The state was sampled every 1000 generations. State estimation was run under the $\mathrm{F} 81+\mathrm{G}$ model for the BBM analysis with wide root distribution to allow assigned outgroup to occur in all areas occupied by the ingroup. This is the most complex model implemented in RASP, with properties expected to yield realism to reconstruct ancestral distribution. The maximum number of areas for this analysis was kept to six.

\section{Phylogenetic signal and saturation}

We applied the phylogenetic signal method of Townsend $[53,54]$, modified to exclude the normalization equation, to determine the Phylogenetic Informativeness (PI) for each gene fragment and each codon position in our dataset. We followed the procedure described by Malm et al. [19] and Klopfstein et al. [55] and calculated site rates in HYPHY 2.1.2 [56], derived from an ultrametric tree with branch lengths proportional to time. PI values were estimated in R (www.r-project.org), which allowed us to visualize the evolutionary rates of each codon position over the evolutionary time of our phylogeny $[19,53]$. We also estimated PI average for each gene codon position by dividing it by gene fragment length for comparison among the genes.
Saturation plots for each gene and codon position were produced by retrieving pairwise uncorrected p-distances, and plotting them against inferred branch-length distances on the tree with the highest likelihood in the tree sample from the Bayesian MCMC analysis [55].

\section{Results}

\section{Gene sequence variation}

The combined and aligned data set included $6095 \mathrm{bp}$ of DNA sequences. The longest fragments were obtained from CAD, $2008 \mathrm{bp}$, followed by COI 3'end (821 bp), COII (684 bp), COI 5'end (671 bp), $28 \mathrm{~S}$ (670 bp), Wnt (466 bp), 16S (447 bp) and H3 (328 bp). Length variation in gene sequences obtained during this study was minimal. There were no introns identified in the alignments but we found a highly variable section within the first 150 bp from the $5^{\prime}$ end of the CAD fragment.

The combined dataset included 3926 conservative sites and 1862 were parsimony-informative. The proportion of variable sites in nuclear and mitochondrial proteincoding genes were similar (28-38\%), while for the ribosomal genes $16 \mathrm{~S}$ and $28 \mathrm{~S}$ it was 25 and $8 \%$, respectively. The $3^{\text {rd }}$ codon position among all protein coding genes was the most parsimony informative, about $80 \%$ of all characters for each gene (Figure 2). Partition Finder divided the dataset into four partitions: 1) $16 \mathrm{~S}, 2) 28 \mathrm{~S}, 1^{\text {st }}$ and $2^{\text {nd }}$ codon position of mitochondrial and nuclear genes; 3) nuclear genes $3^{\text {rd }}$ codon position; 4) mitochondrial genes $3^{\text {rd }}$ codon position (see Additional file 3: Table S3).

\section{Phylogenetic relationships}

The Bayesian analysis of the combined data resulted in a well-resolved and overall highly supported phylogeny (Figure 3). The ingroup Aciliini + Eretini was strongly supported (posterior probability, pp $=1.0$ ) and each tribe was resolved as monophyletic with high support ( $\mathrm{pp}=$ 1.0). In Eretini, the Australian Eretes australis (Erichson, 1842) was recovered as sister to the remaining three taxa in Eretes ( $\mathrm{pp}=1.0)$. In Aciliini, all six genera were recovered as monophyletic with high support ( $\mathrm{pp}=1.0$ ).

The genus Thermonectus was identified as sister group to the rest of Aciliini with high support ( $p p=1.0)$, and was divided into two main clades. The two Afrotropical genera, Aethionectes and Tikoloshanes, were recovered as sister clades with moderate support $(\mathrm{pp}=0.78)$ and basal to the rest of Aciliini excluding Thermonectus ( $\mathrm{pp}=0.96$ ).

The remaining Aciliini was divided into two main clades, a Holarctic clade (Acilius + Graphoderus) and an Australasian-Afrotropical clade (Rhantaticus + Sandracottus), both with high support ( $\mathrm{pp}=1.0)$. The internal resolution within the genera was fully resolved, but, in some cases, especially within Sandracottus, with weak support. 




Figure 2 Proportion of variable, conservative and parsimony informative sites for each gene and each codon position.

Rhantaticus, probably representing a species complex, was divided into an Afrotropical and an Australasian clade.

The Holarctic clade consisted of Graphoderus ( $\mathrm{pp}=1.0$ ) and Acilius ( $\mathrm{pp}=1.0)$ with all internal branches highly supported except three. In Graphoderus the Nearctic species G. liberus was sister to the rest of Graphoderus and two other Nearctic taxa form the following consecutive branches, strongly suggesting a Nearctic origin for the genus. The genus Acilius was highly supported $(\mathrm{pp}=1,0)$ and divided into two main clades, a Nearctic $(\mathrm{pp}=1.0)$ and a Palearctic $(\mathrm{pp}=1.0)$.

The alternative partitioning scheme with six partitions resulted in an identical intergeneric topology, and only differed at one position within Thermonectus and at one position within Graphoderus. The sister group relationship of Tikoloshanes and Aethionectes which had only moderate support in the four partition analysis was given stronger support in the six partition analysis ( $\mathrm{pp}=0.98$ ).

To explore the contribution of CAD we ran separate analyses with CAD alone and all data except CAD, based on the same model of evolution described above. CAD alone, which makes up $31 \%$ of the entire dataset $(35.5 \%$ of parsimony informative sites), resulted in a topology identical to the combined analysis in terms of tribal and intergeneric resolutions (Figure 4). The support values among genera were even higher for some nodes. However, species resolutions in some genera were lower. For example, Palearctic species in the genus Acilius and resolution within the Rhantaticus complex collapsed into polytomies.

Analysis of all data except CAD resulted in a different topology (Figure 5). The intergeneric resolution conflicted with the resolution from CAD alone and from the combined dataset. Aciliini was divided into two main clades: 1)-Thermonectus was grouped as sister to
Rhantaticus + Sandracottus, 2)-Aethionectes was identified as sister group to the genera Graphoderus, Acilius and Tikoloshanes. Tikoloshanes was unexpectedly nested inside an otherwise Holarctic clade ( $\mathrm{pp}=0.81$ ).

\section{Time of divergence}

The estimation of divergence time using the fossil as a crown-node constraint on Acilius suggested congruent ages for the basal nodes with relevant Gondwana breakup ages (Figure 6). The basal divergence of Aciliini and Eretini took place in the mid-Cretaceous around $109 \mathrm{Ma}$ (95\% highest posterior density $=137-88 \mathrm{Ma}$ ). The first branching event within Aciliini was estimated at $92 \mathrm{Ma}$ (114-74 Ma) and involved the divergence of Neotropical Thermonectus from the rest of Aciliini. The second main branching event was the split between Afrotropical genera Aethionectes and Tikoloshanes and the ancestor of the remaining Aciliini (excluding Thermonectus) about 81 Ma (101-65 Ma). Aethionectes and Tikoloshanes diverged at $69 \mathrm{Ma}$ (88-54 Ma), Graphoderus and Acilius at $63 \mathrm{Ma}(78-51 \mathrm{Ma})$, and Rhantaticus and Sandracottus at $56 \mathrm{Ma}$ (71-43 Ma).

Using the fossil calibration as an Acilius stem-node constraint gave significantly younger ages not congruent with Gondwana vicariance events. For example the split between Neotropical Thermonectus and the rest of Aciliini was estimated at $58 \mathrm{Ma}$ (70-49 Ma), Graphoderus and Acilius at $40 \mathrm{Ma}$ (46-36 Ma), and Rhantaticus and Sandracottus at $35 \mathrm{Ma}$ (43-28 Ma).

\section{Biogeographical analysis}

The biogeographical analysis favoured an Neotropical (59\%) over an Afrotropical (23\%) origin of the tribe Aciliini (Figure 7). So optimized, Thermonectus originated in South America and later dispersed to the Nearctic region 


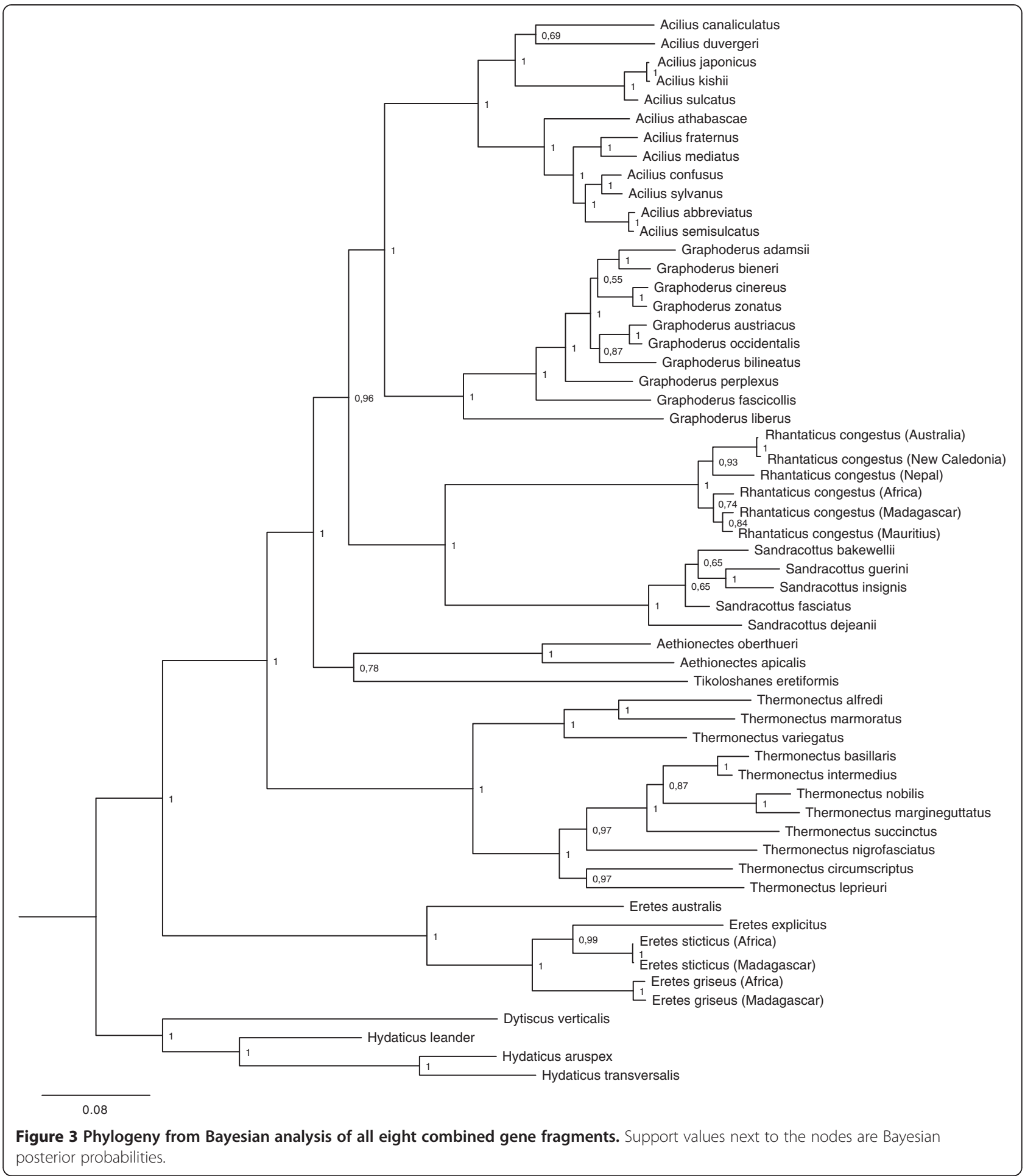

with is in line with the diversity being greatest in the Neotropical part of the New World. However, the ancestral region for Aciliini excluding Thermonectus remained concentrated in the Afrotropical region (80\%) where Aethionectes and Tikoloshanes are found. The deepest divergence within Aciliini is hence between an ancestor in South America and an ancestor in Africa, consistent with a Gondwana vicariance event. This was followed by a series of dispersals to the Palearctic, Oriental, Nearctic and Australian regions during the Cenozoic. The ancestor of the Holarctic Graphoderus + Acilius was optimized to be of Nearctic origin (91\%) 


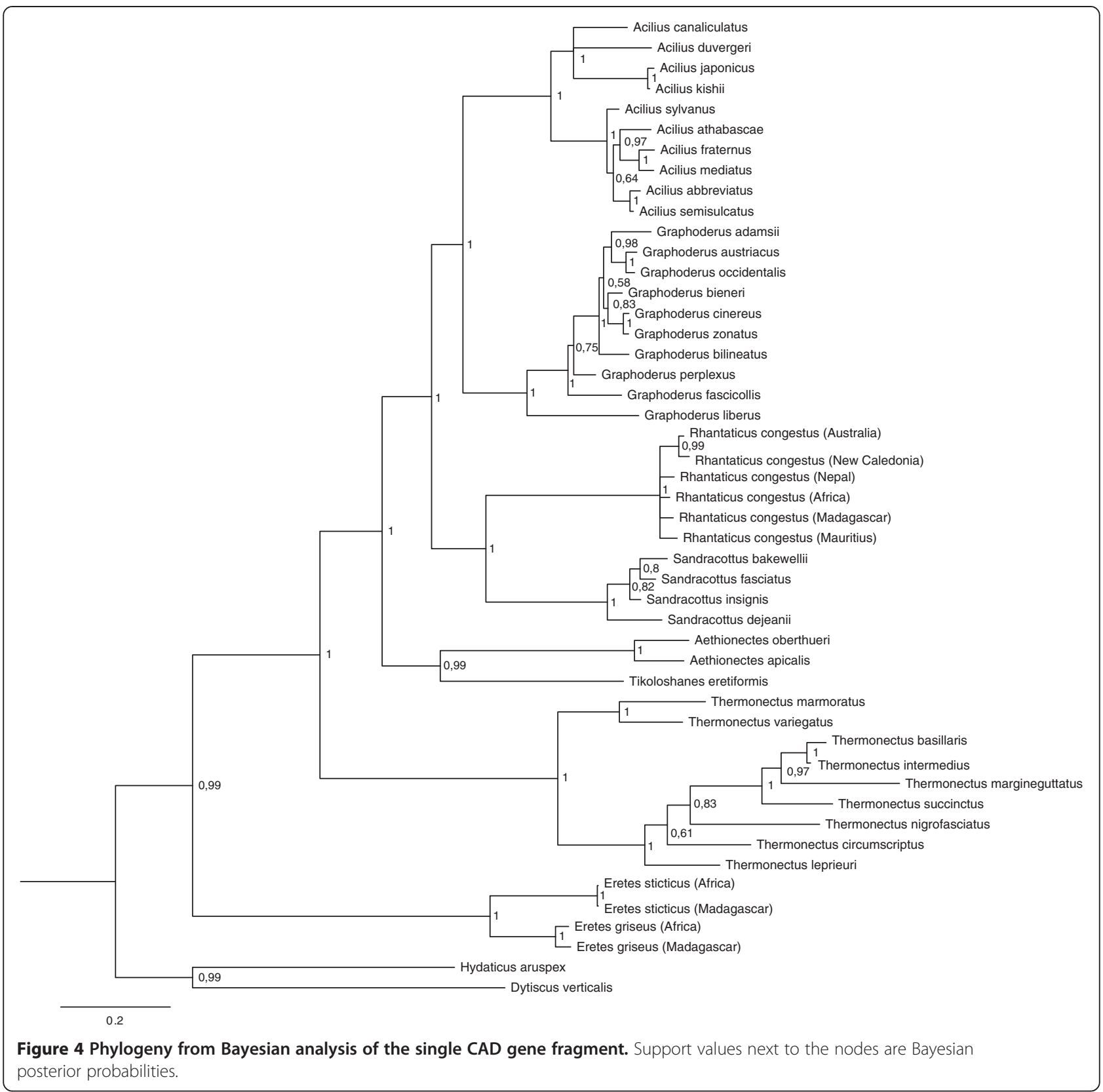

with later dispersals to the Palearctic region within each genus independently. The ancestral distribution of the ancestor of Eretini was inferred to most likely be the Australian region (50\%).

\section{Phylogenetic informativeness}

The phylogenetic informativeness (PI) curves, which attempt to visualize phylogenetic information over time for a given dataset, showed high peaks at ages younger than $20 \mathrm{Ma}$ for the $3^{\text {rd }}$ codon positions of all mitochondrial protein-coding genes (Figure $8 \mathrm{a}-\mathrm{c}$ ). This indicates a partition most informative for the radiation within genera.
The $3^{\text {rd }}$ codon positions of the nuclear protein-coding genes showed the highest PI values between 35-50 Ma and a trailing slow decline over deeper time. For the $1^{\text {st }}$ and $2^{\text {nd }}$ codon positions PI increased slowly with time until 30-50 Ma, and was overall lower for both nuclear and mitochondrial genes and more extended over time.

The original Townsend's PI profile (Figure 8a) gave more narrow peaks than the Modified Townsend's PI profile (Figure 8b), suggesting higher level of "noise" in the data, which can mislead phylogenetic analysis [56]. In the latter analysis without normalization (Figure 8b) these peaks were more extended, relatively lower, and 


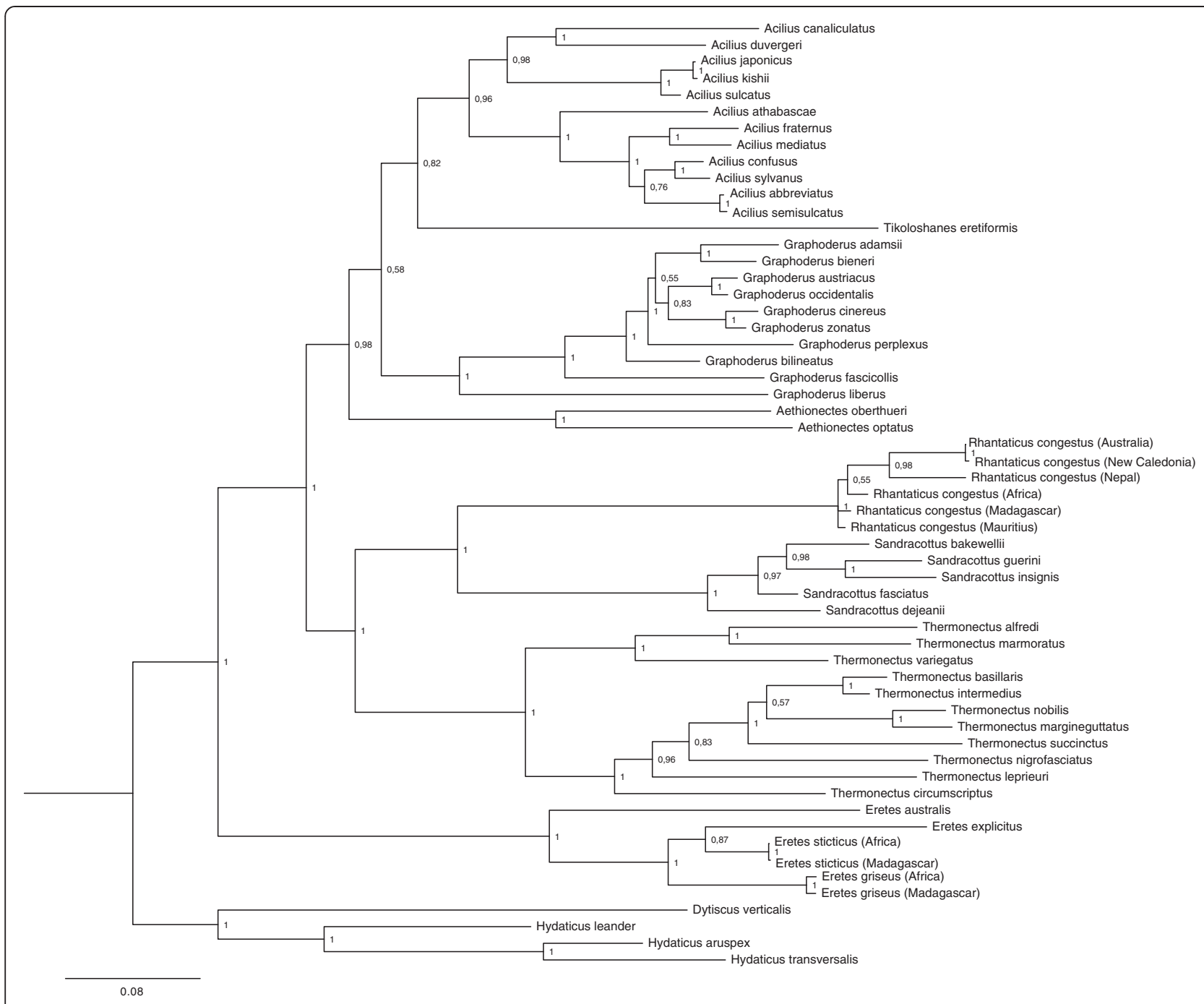

Figure 5 Phylogeny from Bayesian analysis of all combined gene fragments, but excluding CAD. Support values next to the nodes are Bayesian posterior probabilities.

slower evolving positions surpass faster ones at deeper time-scales (for example, CAD $1^{\text {st }}$ codon position shows higher PI at $95 \mathrm{Ma}$ than $3^{\text {rd }}$ codon positions of all mitochondrial protein-coding genes). Third codon position of CAD sticks out as the most informative partition in the dataset. This is partly because this gene fragment is three times longer than the other genes. However averagemodified Townsend's profile displays a PI plot where length differences have been taken into account for comparison across genes and codon positions (Figure 8c). This probably gives the fairest view of comparing partitions and it clearly shows that, 1) most information is in the $3^{\text {rd }}$ codon positions and 2) nuclear $3^{\text {rd }}$ codon positions are superior to mitochondrial per aligned base at ages older than $25 \mathrm{Ma}$. CAD reached the highest PI peak at about $35 \mathrm{Ma}$, but was surpassed by Wnt at deeper time-scales.

\section{Gene saturation}

Saturation plots for each gene and codon position (Figure 9) corresponded well with the PI-modified (Figure $8 \mathrm{~b}-\mathrm{c}$ ) profile plots. The $3^{\text {rd }}$ codon position of mitochondrial protein-coding genes showed a high level of saturation (Figure 9). In the PI plots (Figure 8a) this can be identified by curves with narrow peaks followed by steep declines. The $3^{\text {rd }}$ codon positions of nuclear protein-coding genes were slightly saturated (CAD, H3) or not saturated at all (Wnt) (Figure 9). No saturation was detected in the $1^{\text {st }}$ and $2^{\text {nd }}$ codons in either mitochondrial or nuclear protein-coding genes, suggesting conservative phylogenetic information in these partitions (Figure 9). In the PI plots this is revealed as low but increasing values backwards in time and without any clear peaks or declines. 


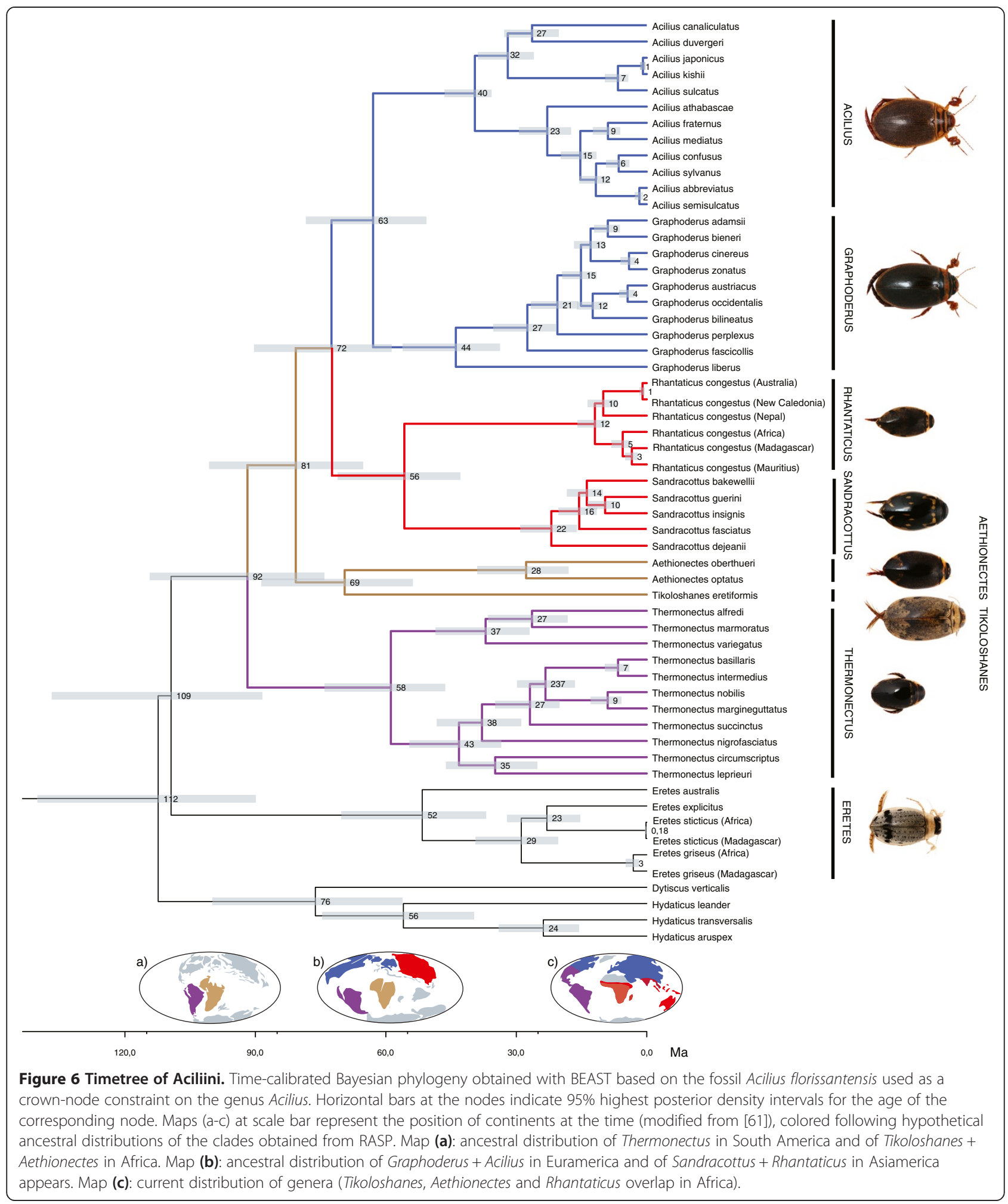

\section{Discussion and conclusion Phylogeny}

In our analyses, Aciliini was always strongly supported as monophyletic to the exclusion of Eretini (all analyses and partitioning schemes). This is consistent with morphological evidence, in particular the aciliine synapomorphy of having both metatibial spurs apically bifid [12]. The weakly supported alternative of a paraphyletic 


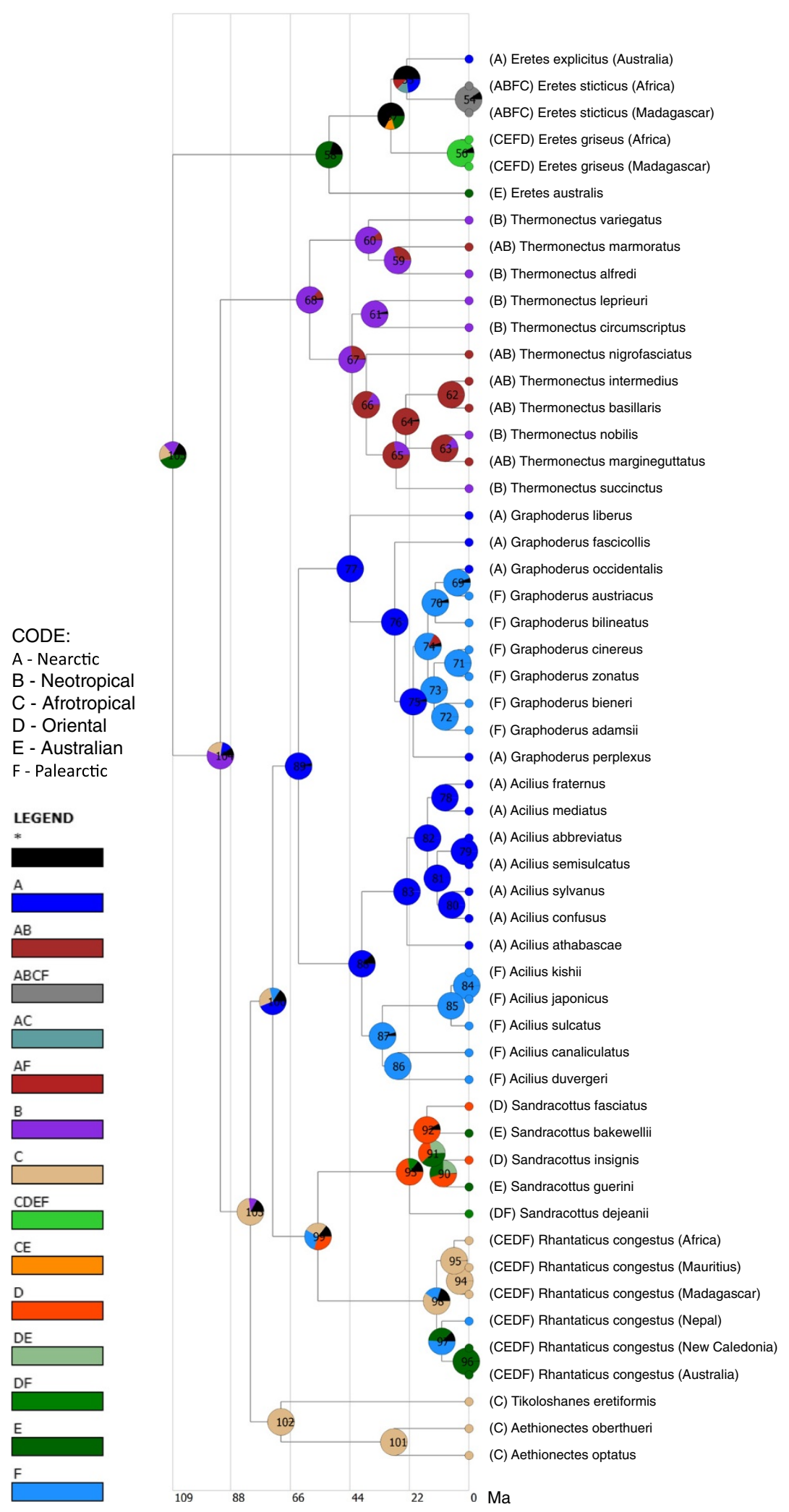

Figure 7 Ancestral distribution inferred from Bayesian analysis with RASP. Pie charts represent ancestral distributions as probabilities coded as follows: A (Nearctic), B (Neotropical), C (Afrotropical), D (Oriental), E (Australian), F (Palearctic). 

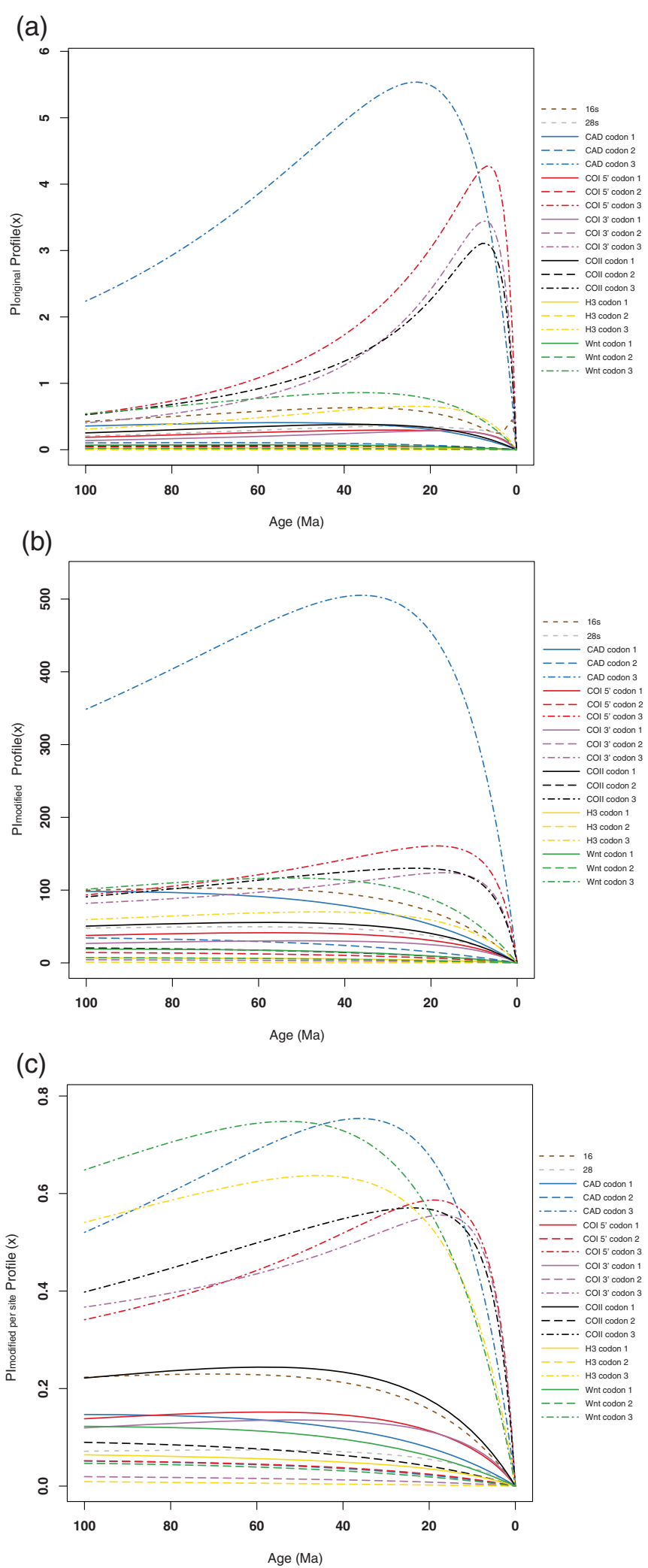

Figure 8 Phylogenetic Informativeness (PI) plots for all data partitions. (a) Ploriginal, (b) PImodified, (c) Plaverage-modified. These analyses differ in the use of a normalization step in Ploriginal, which is removed in PImodified and Plaverage-modified. The latter differ from PImodified in averaging $\mathrm{Pl}$ values over the gene length. The $\mathrm{X}$-axis denotes time from $100 \mathrm{Ma}$ to present, while the $\mathrm{Y}$-axis denotes Phylogentic Informativeness. 


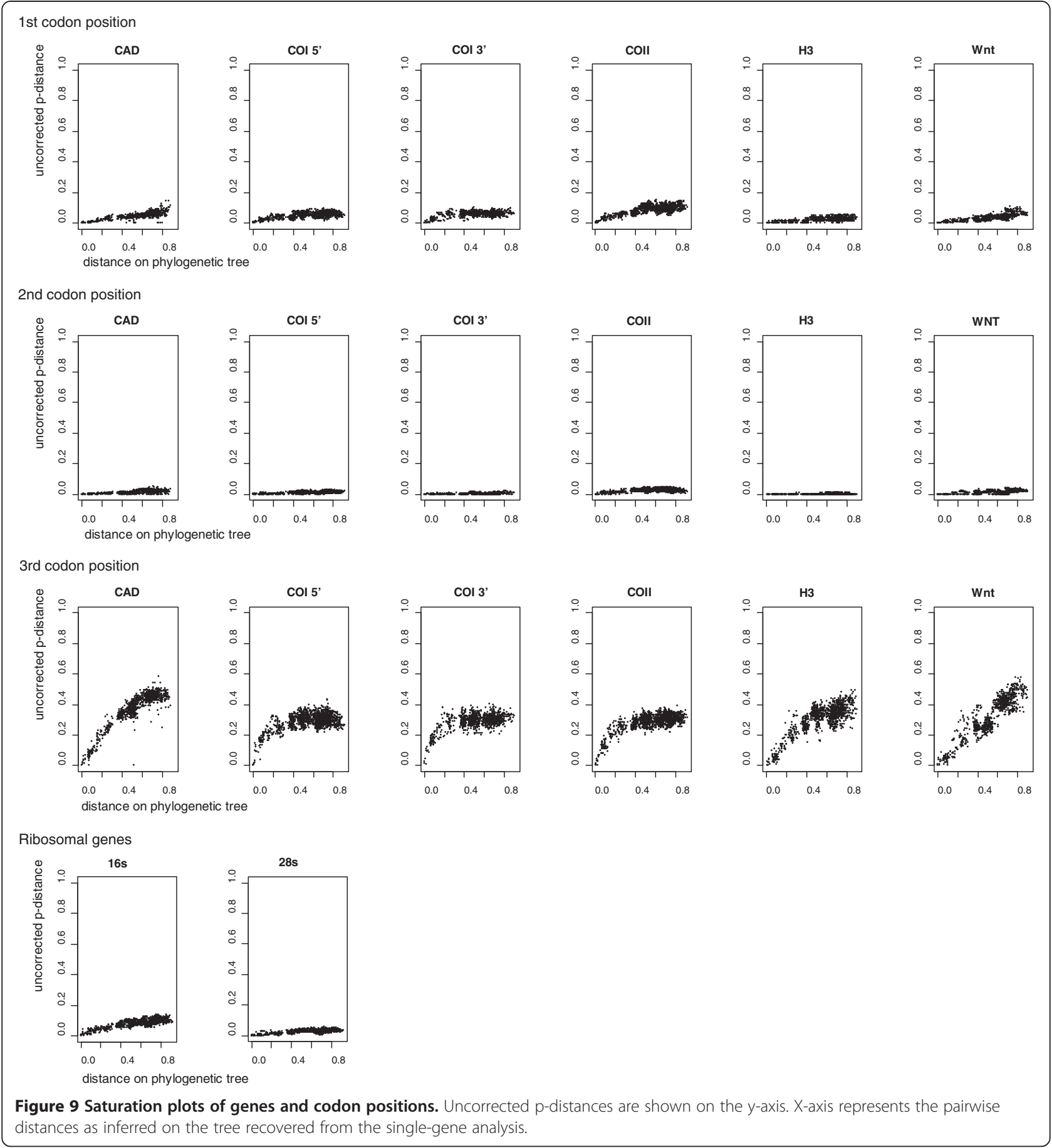

Aciliini with Eretini nested within [14] can therefore be rejected with the present dataset. Eretini is resolved as the sister clade of Aciliini, also corroborating Miller [12]. This clade (Aciliini + Eretini) is supported by the synapomorphy of having the posterodorsal series of setae on metatibia arranged in a strongly oblique linear series with bases of setae contiguous [12]. The distinctive shape of the larvae is also a likely synapomorphy for Aciliini + Eretini and the two pairs of anterior camera- like stemmata could be a further synapomorphy but needs to be examined for more taxa [16]. The monotypic Eretini was also strongly supported as monophyletic but this has never been questioned since the group is well characterized by several distinctive synapomorphies (see $[12,15]$ ).

We recovered a fully resolved backbone and, except in one case, strongly supported relationships between all genera within Aciliini. Three alternative hypotheses had 
been previously identified, i) sister group relationship between Acilius and Thermonectus [9,12,13] ii) Acilius sister to all other Aciliini [7,11], and iii) Acilius and Graphoderus as sister taxa [14]. Our results unequivocally support the third hypothesis, i.e. that Acilius and Graphoderus are sister taxa forming a derived Holarctic clade, corroborating the analyses of Ribera et al. [14]. The Thermonectus + Acilius hypothesis could be rejected and we found instead the New World Thermonectus to be the sister to all other Aciliini. This is a new hypothesis that prompts the investigation of potential morphological synapomorphies for Aciliini excluding the Thermonectus clade. A labial palp with 4-6 spines in the larvae could potentially be a synapomorphy but since Eretes has four spines it is more likely that the bispined labial palp is a synapomorphy for Thermonectus [57]. Since Thermonectus is the most species-rich genus its sister-group placement is in fact supported by the quite common pattern that clade diversity and clade ages are positively correlated. It is worth noting that excluding CAD from the dataset resulted in a clade in which Thermonectus is sister to Oriental-Australian genera Rhantaticus + Sandracottus. The sister group relationship between Rhantaticus and Sandracottus was found in all our analyses as well as in those by Ribera et al. [14]. These are also supported by the synapomorphy of reduced metacoxal lines on the metacoxal process $[5,11]$.

The genus Tikoloshanes, includes the single enigmatic and rarely collected species $T$. eretiformis, which is superficially similar to Eretini [5]. Its placement was previously untested. Our conclusion of a monophyletic Aciliini already precludes a close relationship of Tikoloshanes with either Eretini or Hydaticini, with which the genus bears some similarity based on the arrangement of the metatibial series of spines, as noted by Omer-Cooper [5]. Despite the mixed characters displayed in Tikoloshanes, Omer-Cooper [5] came to the conclusion that Tikoloshanes belong to Aciliini with an affinity to the other Afrotropical aciliine genus Aethionectes. Our results corroborate this hypothesis, even though it was the only intergeneric node not supported with a posterior probability greater than 0.95 in the four-partition analysis (0.98 in the six partition analysis). Again, the placement changed when CAD was removed resulted in Tikoloshanes nested within the Holarctic clade, a very unlikely conclusion.

The effect of removing the $2000 \mathrm{bp}$ CAD fragment should be seen in the light of the data partitions that come to dominate the phylogenetic signal in the new dataset (c.f. Figure 3b). The remaining subset becomes dominated by the mitochondrial genes, since the other nuclear genes are relatively shorter. Most of the phylogenetic signal from the mitochondrial genes is provided by the clearly saturated third codon positions (Figure 9).
Placement of a single long branched taxon like Tikoloshanes is, likely to be more uncertain when based on a higher proportion of saturated data.

\section{Biogeography and divergence time}

The biogeographical distribution together with the phylogeny of Aciliini and Eretini firmly places the origin of Aciliini in the Southern Hemisphere. The basalmost clades are all optimized to Australia (Eretes), South America (Thermonectus) and Africa (Aethionectes + Tikoloshanes). The present distribution could be explained by a vicariance event following the breakup of Gondwana. West Gondwana (South America and Africa) and East Gondwana (India, Madagascar, Australia) was the first major break-up event at about 165-130 Ma [58,59]. The split between ancestral Eretini (optimized to Australian region) and ancestral Aciliini (optimized to S. America and Africa) would follow such a pattern and the age using the fossil calibration on the Acilius crown-node was estimated to an interval encompassing that geological age: 95\% HPD = 138-88 Ma. Likewise, an early lineage split within Aciliini would have followed the second major break-up in West Gondwana between South America (leading to the divergence of Thermonectus in the Neotropical region) and Africa when the South Atlantic ocean started to open at about $135 \mathrm{Ma}$ with land connections likely until around $105 \mathrm{Ma}$ [59]. With the same calibration point this split in the phylogeny was estimated to an interval allowing for a geological vicariance event explanation: (114-74 Ma). At some point the ancestor of the Australasian (Sandracottus + Rhantaticus) and Holarctic (Acilius + Graphoderus) clades dispersed out-of-Africa, and this happened long before the Tethys sea actually closed and a land connection was established [60]. Most Aciliini being capable of flight and e.g. Rhantaticus having colonized islands like Mauritius and New Caledonia in recent times, this seems reasonable. The out-of-Africa node was dated to 100-65 Ma and during this time Laurasia was divided into an Euramerican and an Asiamerican continent, with a number of smaller continental fragments between these and Africa [61]. The split between the ancestor of Holarctic Graphoderus + Acilius, optimized to have a Nearctic origin, and the ancestor of Australasian Rhantaticus + Sandracottus, most probably with a Palearctic/Oriental origin, were dated to 5990 Ma. The Turgai Strait separated eastern Palearctic from Euramerica during this period [61] and the two clades seem to have their origin on respective sides.

However, estimations using the fossil as an Acilius stem-node calibration dated the relevant nodes of the tree to be too young for some of these events. The Aciliini-Eretini split is too young to be explained by the vicariance event of western and eastern Gondwana breaking up (83-57 Ma). The split between Neotropical 
Thermonectus and the rest of Aciliini is too young for the vicariant breakup of South America and Africa (70-49 Ma).

Compared to the crown-group calibration this is a less parsimonious solution, as it requires more transoceanic dispersals events to be invoked. That said, we agree with de Quieroz [62] that we have previously underestimated how geological time scales can make the most improbable dispersal event probable. For increased precision around the evolutionary history of Aciliini, future studies are needed which includes multiple primary calibration points and takes the full uncertainty into account through the priors. Since fossils in this group are scarce this will probably have to be done at higher subfamily, family or superfamily level.

\section{Phylogenetic informativeness in CAD}

In recent years $\mathrm{CAD}$ has become commonly used for resolving both shallow and deep evolutionary relationships of insects $[19,27,63]$. Evaluation of the performance of different gene fragments is often done by comparing single gene tree reconstructions with a total evidence hypothesis or a hypothesis derived from accumulated previous work [27]. But the relative phylogenetic informativeness of genes can also be more directly quantified over time in relation to its evolutionary rate $[53,54,64]$. While the extrapolation of Townsend's original formulation of the method [39] beyond the four-taxon case has been questioned [64], modifications have been proposed that seem to more accurately capture the effect of saturation [19]. Our analyses suggested variable phylogenetic informativeness for gene-and codon partitions over the time-scale in this study. CAD contributed substantially to the resolved and highly supported backbone of the phylogenetic tree as evident both from PI plots (Figure $8 \mathrm{ab}$ ) and from comparing the single gene tree with the total evidence analysis. Analyzed alone CAD recovered both tribes and all genera as monophyletic and resolves the deeper nodes in agreement with a Gondwana breakup influence. This confirms previous studies in Diptera [17] and Hymenoptera [56] where likewise CAD alone successfully resolved Mesozoic-aged divergences in agreement with independent evidence. An evaluation of nuclear genes in Coleoptera [27] also scored $\mathrm{CAD}$ as the best performing gene overall among the ones compared, but CAD failed to recover some well-supported Mesozoic-aged clades. This might have had more to do with a poor taxon sampling for this scale and the known effects of taxon sampling $[65,66]$. For the reconstruction of the Trichoptera tree of life, CAD was surpassed in phylogenetic Informativeness by RNA Polymerase II (POL) at deeper time scales [19].

At 2008 bp, CAD was the longest gene in our dataset, more than three times longer than mitochondrial genes and almost five times longer than other nuclear genes in our dataset. As a consequence, CAD was our most informative gene fragment. To compare its informativeness per site with other genes, we averaged the modified Townsend's PI profile [19] by dividing PI values with the gene length for each gene and codon position [54]. The Average-modified PI profile indicated that the $3^{\text {rd }}$ codon position of CAD was the most informative between 15 and $50 \mathrm{Ma}$ closely followed and surpassed by the $3^{\text {rd }}$ codon position of Wnt over deeper time. This mirrors the comparison with POL [19], which begs for a future comparison between Wnt and POL over deeper Mesozoic timescales. Moreover, the Average-modified PI plot identified $3^{\text {rd }}$ codon positions of nuclear genes in general as more informative already for relationships older than $15 \mathrm{Ma}$ compared to $3^{\text {rd }}$ codon positions in mitochondrial genes.

It has been reported that $\mathrm{CAD} 3^{\text {rd }}$ codon position demonstrates heterogeneity in base composition potentially indicating saturation which can mislead phylogenetic analyses $[19,37,67]$. In our analysis, $3^{\text {rd }}$ codon position of CAD (as well as the $3^{\text {rd }}$ codon positions in Histone 3) was slightly saturated but far less than in mitochondrial genes. Wnt did not show any signs of saturation, even at $3^{\text {rd }}$ codon positions, showing great promise as a marker for deeper relationships but is perhaps underused today due to shortage of primers and protocols to amplify longer fragments. The Wnt gene is also known to produce paralogs for some insect groups [68] and can present alignment problems [27]. The 466 bp target fragment in this study showed no evidence of paralogs, insertions or deletions and was unproblematic to align. The CAD alignment in contrast, displayed a markedly highly variable section located at the 5 ' end, including a 3-9 bp long indel, but which translated correctly to amino acids. This variable section, part of the small chain of CPS [17,37], provides CAD with phylogenetic information also at younger levels e.g. within genera.

\section{Availability of supporting data}

The datamatrix for the phylogenetic analysis and Additional file 1: Table S1, Additional file 2: Table S2, Additional file 3: Table S3 are deposited at the DRYAD data depository (DOI:10.5061/dryad.052ng).

\section{Additional files}

Additional file 1: Table S1. Specimen data and NCBI accession numbers.

Additional file 2: Table S2. Primers. Primers used for amplification and sequencing were derived from several sources.

Additional file 3: Table S3. Summary of the partitions and models. The best-fit partitioning scheme and model according to PartitionFinder. 


\section{Competing interests}

The authors declare that they have no competing interests.

\section{Authors' contributions}

$J B$ and RB conceived the study. RB and KBM performed the lab work. JB and KBM provided crucial samples. RB and JB performed the analysis and wrote the first draft. All authors contributed to the final manuscript. All authors read and approved the final manuscript.

\section{Acknowledgements}

We are very grateful to Michael Balke (Zoologisches Staatsammlung Munchen) and to Ignacio Ribera (Institut de Biologia Evolutiva, Spain) for supplying specimen and DNA of Sandracottus spp. and Eretes explicitus which helped to complete our dataset. We wish to thank Seraina Klopfstein (Swedish Museum of Natural History, Sweden) and Tobias Malm (University of "Eastern Finland", Finland) who kindly provided valuable insights to the methods regarding saturation and phylogenetic information content. Stella Papadopoulou read through the manuscript to check the language A. Southwood, Department of Economic Affairs, Environment and Tourism, Greenacres, E. Cape Prov., S. Africa, supported permit arrangements. We are very grateful for the hospitality by Mr and Mrs Hansen, Sterkstroom, thanks to whom one specimen of Tikoloshanes could finally be collected. The work was supported by the Swedish research council (Vetenskapsrådet) through the grant 621-2009-3744, and fieldwork by Helge Ax:son Johnsons stiftelse, both to J. Bergsten. Portions of this work were supported by NSF grant \#DEB-0845984 to K.B. Miller.

\section{Author details}

${ }^{1}$ Department of Entomology, Swedish Museum of Natural History, Box 50007, SE-104 05 Stockholm, Sweden. ${ }^{2}$ Department of Zoology, Stockholm University, SE-106 91 Stockholm, Sweden. ${ }^{3}$ Department of Biology and Museum of Southwestern Biology, University of New Mexico, Albuquerque, NM 87131, USA.

Received: 19 September 2013 Accepted: 30 December 2013 Published: 14 January 2014

\section{References}

1. Nilsson AN: Dytiscidae. In World Catalogue of Insects: 1-395. 2001.

2. Larson DJ, Alarie Y: RRE: Predaceous Diving Beetles (Coleoptera: Dytiscidae) of the Nearctic Region, with Emphasis on the Fauna of Canada and Alaska. Ottawa: NRC Research Press; 2000.

3. Bergsten J, Miller KB: Taxonomic revision of the Holarctic diving beetle genus Acilius Leach (Coleoptera: Dytiscidae). Syst Entomol 2005, 31:145-197.

4. Nilsson AN, Holmen M: The aquatic Adephaga (Coleoptera) of Fennoscandia and Denmark: II: dytiscidae. Fauna Entomol Scand 1995, 32:192pp.

5. Omer-Cooper J: Tikoloshanes, a new genus of Dytiscidae (Col.) from South Africa. Proc R Entomol Soc London 1956:79-82.

6. Bergsten J, Miller KB: Phylogeny of diving beetles reveals a coevolutionary arms race between the sexes. PloS one 2007, 2:e522.

7. Erichson WF: Genera Dyticeorum. Berolini: Nietackianis; 1832:48.

8. Dejean PFMA: Catalogue Des Coléoptères De La Collection De M. Le Comte Dejean. Paris: Livraisons 1 \& 2; 1833:176.

9. Aubé C: Hydrocanthares Et Gyriniens. In Species Général Des Coléoptères De La Collection De M. Le Comte Dejean. 6th edition. Edited by Dejean PF. Paris: Méquignon Père et Fils; 1838:804.

10. Régimbart M: Étude Sur La Classification Des Dytiscidae. Annales de la Société Entomologique de France (5) 1879, 8(1878):447-466. + pl. 10:1-28.

11. Sharp D: On aquatic carnivorous coleoptera or dytiscidae. Sci Trans $R$ Dublin Soc 1882, 2(2):179-1003. +psl. 7-18.

12. Miller KB: Revision of the Neotropical Genus Hemibidessus Zimmermann (Coleoptera: Dytiscidae: Hydroporinae: Bidessini). Aquat Insects 2000, 23:253-275.

13. Miller KB: On the phylogeny of the Dytiscidae (Insecta: Coleoptera) with emphasis on the morphology of the female reproductive system. Insect Syst Evol 2001, 32:45-92.

14. Ribera I, Vogler AP, Balke M: Phylogeny and diversification of diving beetles (Coleoptera: Dytiscidae). Cladistics 2008, 24:563-590.

15. Miller KB: Revision of the Genus Eretes Laporte, 1833 (Coleoptera: Dytiscidae). Aquat Insects 2002, 24:247-272.
16. Mandapaka K, Morgan RC, Buschbeck EK: Twenty-eight retinas but only twelve eyes: an anatomical analysis of the larval visual system of the diving beetle Thermonectus marmoratus (Coleoptera: Dytiscidae). J Comp Neurol 2006, 497:166-181.

17. Moulton JK, Wiegmann BM: Evolution and phylogenetic utility of CAD (rudimentary) among Mesozoic-aged Eremoneuran Diptera (Insecta). Mol Phylogenet Evol 2004, 31:363-378.

18. Richards S, Gibbs RA, Weinstock GM, Brown SJ, Denell R, Beeman RW, Gibbs R, Bucher G, Friedrich M, Grimmelikhuijzen CJP, Klingler M, Lorenzen M, Roth S, Schröder R, Tautz D, Zdobnov EM, Muzny D, Attaway T, Bell S, Buhay CJ, Chandrabose MN, Chavez D, Clerk-Blankenburg KP, Cree A, Dao M, Davis C, Chacko J, Dinh H, Dugan-Rocha S, Fowler G, et al: The genome of the model beetle and pest Tribolium castaneum. Nature 2008, 452:949-955.

19. Malm T, Johanson $K$, Wahllberg N: The evolutionary history of Trichoptera (Insecta): a case of successful adaptation to life in freshwater. Syst Entomol 2013 38:459-473.

20. Danforth BN, Fang J, Sipes S: Analysis of family-level relationships in bees (Hymenoptera: Apiformes) using $28 \mathrm{~S}$ and two previously unexplored nuclear genes: CAD and RNA polymerase II. Mol Phylogenet Evol 2006, 39:358-372.

21. Praz CJ, Müller A, Danforth BN, Griswold TL, Widmer A, Dorn S: Phylogeny and biogeography of bees of the tribe Osmiini (Hymenoptera: Megachilidae). Mol Phylogenet Evol 2008, 49:185-197.

22. Winterton SL, Hardy NB, Wiegman BM: On wings of lace: phylogeny and Bayesian divergence time estimates of Neuropterida (Insecta) based on morphological and molecular data. Syst Entomol 2010, 35:349-378.

23. Johanson KA, Malm T: Testing the monophyly of Calocidae (Insecta: Trichoptera) based on multiple molecular data. Mol Phylogenet Evol 2010, 54:535-541.

24. Regier JC, Zwick A, Cummings MP, Kawahara AY, Cho S, Weller S, Roe A, Baixeras J, Brown JW, Parr C, Davis DR, Epstein M, Hallwachs W, Hausmann A, Janzen DH, Kitching IJ, Solis MA, Yen S-H, Bazinet AL, Mitter C: Toward reconstructing the evolution of advanced moths and butterflies (Lepidoptera: Ditrysia): an initial molecular study. BMC Evol Biol 2009, 9:280.

25. Dole SA, Jordal BH, Cognato Al: Polyphyly of xylosandrus reitter inferred from nuclear and mitochondrial genes (Coleoptera: Curculionidae: Scolytinae). Mol Phylogenet Evol 2010, 54:773-782.

26. Jordal BH, Sequeira AS, Cognato Al: The age and phylogeny of wood boring weevils and the origin of subsociality. Mol Phylogenet Evol 2011 59:708-724.

27. Wild AL, Maddison DR: Evaluating nuclear protein-coding genes for phylogenetic utility in beetles. Mol Phylogenet Evol 2008, 48:877-891.

28. Maddison DR, Arnold EA: A review of the Bembidion (Odontium) aenulum subgroup (Coleoptera: Carabidae), with description of a new species. ZOOTAXA 2009, 2214:45-61.

29. Mousseau T, Sikes DS: Almost but not quite a subspecies: a case of genetic but not morphological diagnosability in Nicrophorus (Coleoptera: Silphidae). Biol J Linn Soc 2011, 102:311-333.

30. Kaltenpoth M, Steiger S: Unearthing carrion beetles' microbiome: characterization of bacterial and fungal hindgut communities across the Silphidae. Mol Ecol 2013, doi:10.1111/mec.12469.

31. Sikes DS, Venables C: Molecular phylogeny of the burying beetles (Coleoptera: Silphidae: Nicrophorinae). Mol Phylogenet Evol 2013, 69:552-565.

32. Maddison DR: Systematics of the North American beetle subgenus Pseudoperyphus (Coleoptera: Carabidae: Bembidion) based upon morphological, chromosomal, and molecular data. Ann Carnegie Mus 2008, 77:147-193.

33. Maddison DR, Toledano L, Sallenave S, Roig-Junent S: Phylogenetic relationships of the South American ground beetle subgenus Chilioperyphus Jeannel (Coleoptera: Carabidae: Trechinae: Bembidiini: Bembidion Latreille). ZOOTAXA 2013, 3636:547-560.

34. Maddison DR: Phylogeny of Bembidion and related ground beetles (Coleoptera: Carabidae: Trechinae: Bembidiini: Bembidiina). Mol Phylogenet Evol 2012, 63:533-576.

35. Sharanowski BJ, Dowling APG, Sharkey MJ: Molecular phylogenetics of Braconidae (Hymenoptera: Ichneumonoidea), based on multiple nuclear genes, and implications for classification. Syst Entomol 2011, 36:549-572.

36. Miller KB, Bergsten J, Whiting MF: Phylogeny and classification of the tribe Hydaticini (Coleoptera: Dytiscidae): partition choice for Bayesian analysis with multiple nuclear and mitochondrial protein-coding genes. Zool Scr 2009, 38:591-615.

37. Miller KB, Bergsten J: Phylogeny and classification of whirligig beetles (Coleoptera: Gyrinidae): relaxed-clock model outperforms parsimony and time-free Bayesian analyses. Syst Entomol 2012, 37:706-746. 
38. Edgar RC: MUSCLE: multiple sequence alignment with high accuracy and high throughput. Nucleic Acids Res 2004, 32:1792-1797.

39. Tamura K, Peterson D, Peterson N, Stecher G, Nei M, Kumar S: MEGA5: molecular evolutionary genetics analysis using maximum likelihood, evolutionary distance, and maximum parsimony methods. Mol Biol Evol 2011, 28:2731-2739.

40. Peña C, Malm T: VoSeq: a voucher and DNA sequence web application. Plos one 2012, 7:e39071.

41. Lanfear R, Calcott B, Ho SYW, Guindon S: Partitionfinder: combined selection of partitioning schemes and substitution models for phylogenetic analyses. Mol Biol Evol 2012, 29:1695-1701.

42. Ronquist F, Teslenko M, Van der Mark P, Ayres DL, Darling A, Höhna S, Larget B, Liu L, Suchard MA, Huelsenbeck JP: MrBayes 3.2: efficient Bayesian phylogenetic inference and model choice across a large model space. Syst Biol 2012, 61:539-542.

43. Huelsenbeck JP, Larget B, Alfaro ME: Bayesian phylogenetic model selection using reversible jump Markov chain Monte Carlo. Mol Biol Evol 2004, 21:1123-1133.

44. Drummond AJ, Rambaut A: BEAST: Bayesian evolutionary analysis by sampling trees. BMC Evol Biol 2007, 7:214

45. Wilgenbusch JC, Warren DL, Swofford DL: AWTY: a system for graphical exploration of MCMC convergence in Bayesian phylogenetic inference. 2004. http://ceb.csit.fsu.edu/awty.

46. Nylander JAA, Wilgenbusch JC, Warren DL, Swofford DL: AWTY (are we there yet?): a system for graphical exploration of MCMC convergence in Bayesian phylogenetics. Bioinformatics (Oxford, England) 2008, 24:581-583.

47. Drummond AJ, Ho SYW, Phillips MJ, Rambaut A: Relaxed phylogenetics and dating with confidence. PLoS biology 2006, 4:e88.

48. Evanoff E, Mcintosh WC, MPC: Stratigraphic summary and 40Ar/39Ar. geochronology of the Florissant Formation, Colorado. In Proceedings of the Denver Museum of Nature and Science, Volume 4. 1st edition. Edited by Evanoff E, Gregory Wodzicki KM, Johnson KR. 2001:1-16.

49. Wickham HF: New fossil Coleoptera from Florissant. Am J Sci Arts 1909, 4:126-130.

50. Ho SYM: Calibrating molecular estimates of substitution rates and divergence times in birds. J Avian Biol 2007, 38:409-414.

51. Ho SYW, Phillips MJ: Accounting for calibration uncertainty in phylogenetic estimation of evolutionary divergence times. Syst Biol 2009, 58:367-380

52. Yu Y, Harris AJ, He XJ: RASP (Reconstruct Ancestral State in Phylogenies) 2.1 beta. 2013. http://mnh.scu.edu.cn/soft/blog/RASP.

53. Townsend JP: Profiling phylogenetic informativeness. Syst Bio/ 2007, 56:222-231.

54. Townsend JP, Su Z, Tekle Yl: Phylogenetic signal and noise: predicting the power of a data set to resolve phylogeny. Syst Biol 2012, 61:835-849.

55. Klopfstein S, Vilhelmsen L, Heraty JM, Sharkey M, Ronquist F: The hymenopteran tree of life: evidence from protein-coding genes and objectively aligned ribosomal data. PLOS ONE 2013, 8:e69344.

56. Pond SLK, Frost SDW, Muse SV: HyPhy: hypothesis testing using phylogenies. Bioinformatics (Oxford, England) 2005, 21:676-679.

57. Bertrand H: Larves Et Nymphes Des Coléoptères Aqua- Tiques Du Globe. France: F. Paillart; 1972:804.

58. Yoder AD, Nowak MD: Has vicariance or dispersal been the predominant biogeographic force in Madagascar? Only time will tell. Annu Rev Ecol Evol Syst 2006, 37:405-431.

59. Stephen M: The breakup history of Gondwana and its impact on pre-Cenozoic floristic provincialism. Aust J Bot 2001, 49:271-300.

60. Hrbek T, Meyer A: Closing of the Tethys Sea and the phylogeny of Eurasian killifishes (Cyprinodontiformes: Cyprinodontidae). J Evol Biol 2003, 16:17-36.

61. Sanmartin I, Enghoff $H$, Ronquist F: Patterns of animal dispersal, vicariance and diversification in the Holarctic. Biol J Linn Soc 2001, 73:345-390.

62. De Queiroz A: The resurrection of oceanic dispersal in historical biogeography. Trends Eco Evol 2005, 20:68-73

63. Wiegmann BM, Trautwein MD, Kim J-W, Cassel BK, Bertone MA, Winterton $S L$, Yeates DK: Single-copy nuclear genes resolve the phylogeny of the holometabolous insects. BMC Biol 2009, 7:34.

64. Klopfstein S, Kropf C, Quicke DLJ: An evaluation of phylogenetic informativeness profiles and the molecular phylogeny of diplazontinae (Hymenoptera, Ichneumonidae). Syst Biol 2010, 59:226-241.
65. Zwickl DJ, Hillis DM: Increased taxon sampling greatly reduces phylogenetic error. Syst Biol 2002, 51:588-598.

66. Heath TA, Hedtke SM, Hillis DM: Taxon sampling and the accuracy of phylogenetic analyses. J Syst Evol 2008, 46:239-257.

67. Xia X, Xie Z, Salemi M, Chen L, Wang Y: An index of substitution saturation and its application. Mol Phylogenet Evol 2003, 26:1-7.

68. Danforth BN, Brady SG, Sipes SD, Pearson A: Single-copy nuclear genes recover cretaceous-age divergences in bees. Syst Biol 2004, 53:309-326.

doi:10.1186/1471-2148-14-5

Cite this article as: Bukontaite et al:: The utility of CAD in recovering Gondwanan vicariance events and the evolutionary history of Aciliini (Coleoptera: Dytiscidae). BMC Evolutionary Biology 2014 14:5.

\section{Submit your next manuscript to BioMed Central and take full advantage of:}

- Convenient online submission

- Thorough peer review

- No space constraints or color figure charges

- Immediate publication on acceptance

- Inclusion in PubMed, CAS, Scopus and Google Scholar

- Research which is freely available for redistribution 